\title{
Analysis of Biden's Foreign Policy to the Islamic Republic of Iran
}

\author{
Sana Chebil
}

\begin{abstract}
Before and after the election, Joe Biden has stated that one of his foreign policy priorities is to formulate and pursue a new US policy towards Iran. At the heart of Biden's "Iranian politics" is his return to the JCPOA. However, there are ambiguities about this policy and how the United States will return to the JCPOA agreement. Therefore, this article tries to answer the question of the nature, components, and coordinates of Biden's foreign policy towards Iran and what it will be like? By documenting and analyzing the letters, and statements made by Biden and his foreign policy team, it is argued that Biden's foreign policy discourse is "liberal internationalism." Biden's nuclear policy is also based on a thematic and phased link to return to the JCPOA in the first step, strengthen and expand its provisions, extend its time in the second step, and extend it to Iran's missile program regional influence in the third step.
\end{abstract}

Keywords: JCPOA, Liberal Internationalism, Liberal Institutionalism, Multilateralism, Transatlanticism, Human Rights Expansion of Democracy, International Interventionism, Maximum Pressure

\section{Introduction}

US President Joe Biden has developed a new policy towards the Islamic Republic of Iran, one of his government's foreign policy priorities since Biden and his foreign policy team believe that Trump's campaign of maximum pressure on Iran has failed to achieve its goals. Therefore, to get rid of this failed strategy, a new policy must be formulated and implemented that meets the strategic goals and interests of the United States. At the heart of Biden's Iranian politics is the issue of Iran's nuclear program. President Biden made it clear before and after the election that his government would return to the negotiation table if Iran returned to the JCPOA. However, Biden's general policy and the nuclear policy of commitment versus his commitment to Iran are ambiguous. Therefore, the purpose of this article is to analyze what Biden's foreign policy towards the Islamic Republic of Iran is; So that we try to answer the question of what is the nature, components, and coordinates of Biden's foreign policy towards Iran and what will it be like? At the heart of the main question are other sub-questions that need to be answered. What is Biden's foreign policy discourse? What are the processes and stages of nuclear policy versus commitment? By examining documents and analyzing Biden's statements, letters, and declarations, Anthony Blinken, the State Department nominee, Jake Sullivan, the national security adviser, and William Burns, the CIA director in the Biden administration, are trying to answer these questions. To achieve this goal, four speeches and conclusions are presented. In the first part, Biden's foreign policy discourse is explained. The second part discusses Biden's principles of foreign policy in the context of this discourse. Biden's interests, goals, tools, and foreign policy doctrine are summarized and explained in the third section. The fourth part is devoted to analyzing what Biden's nuclear policy is toward Iran. Finally, the findings of the article are summarized in the form of different scenarios in the conclusion. a) Biden Foreign Policy Discourse: Liberal Internationalism

Biden's foreign policy discourse within the framework of the Democratic Party's foreign policy discourse is "liberal nationalism." (Kupchan: 2020).

However, some call this discourse "liberal realism" (Ikenberry and Kupchan:2004) and "Progressive realism" (Wright:2006, 2016,2020; Nye: Aug.25.2006). Despite their literal differences, these three titles are spiritually standard and imply a single system of meaning. In this way, the system, ideas, and purpose of realism and liberalism are combined in a single system of signification. The central idea of this discourse is to change the world and the international system through the exercise of American power, will, and aspirations (Kupchan: 2020 p.299).

Thus, on the one hand, the tradition of liberalism emphasizes democratic principles, liberal values, diplomacy, cooperation, Multilateralism, and institutionalism in American foreign policy. On the other hand, based on the tradition of realism, the need to use force in the context of coercive and deterrent diplomacy and US military intervention at the international level is acknowledged and recommended. So, the grand strategy of liberal internationalism is to integrate the dualistic realism and idealism of internationalism. This strategy involves combining power, cooperation, and partnership to combat and counter US threats and enemies. Maintaining and sustaining American peace means designing, establishing, and defending a regular international order by the United States.

Furthermore, the justification of US military intervention in international affairs is based on national interests and American ideals (Kupchan: 2020, pp27, 29). American foreign policy has always faced the paradox of simultaneously using the undisputed power of this country and its liberal values. Realists deny and oppose the decisive role of democratic and liberal values and ideals in American foreign policy and focus only on pursuing national interests. 
On the other hand, idealists see these values and ideals as the determinants of American foreign policy and its inherent component. Democrats believe that this paradox can be resolved in a liberal or progressive liberal foreign policy based on the discourse of liberal internationalism. In such a way that based on a coherent and integrated macro strategy, hard military power and soft power based on liberal and democratic values and ideals are combined and applied in smart power (Nye: Aug.25.2006).

The foreign policy of liberal internationalism is guided by the ideals and realities of power. America's goals and interests, including the liberal international order, combine American supremacy and its fundamental liberal principles and values. In a way, the United States uses its superior power to establish and maintain consensual and legitimate international order and governance mechanisms. (Ikenberry and Kupchan :2004, pp.38).

The essential principles of liberal internationalism are free international trade; Multilateralism; International institutionalism; Collaborative and collective security; Protection and respect for human rights; Development and expansion of democracy; Collective solution of international problems and issues; The gradual and evolutionary transformation of the international order; And the rule of law (Ikenberry:2009, pp 71-73, Ikenberry: 2018 pp 7-23).

Biden and his foreign policy team's character, attitudes, thoughts, and actions clearly show that they are liberal internationalists and think and act in the discourse of liberal internationalism. Hence, the Biden government's foreign policy discourse will be liberal internationalism because they consider themselves committed to the principles, goals, and strategy of internationalist or liberal realist foreign policy. In liberal internationalist discourse, they seek to integrate the teachings, ideals, and principles of liberalism and realism into American foreign policy. On the one hand, like liberals on international free trade, Multilateralism; International Institutionalism. Collaborative and collective security; Protection and respect for human rights; Development and expansion of democracy; Collective solution of international problems and issues; gradual and evolutionary transformation of the international order; And emphasize the rule of law. On the other hand, like the realists, they see the use of force, violence, and military deterrence as necessary to support US diplomacy (Burns and Sullivan:2019; Burns:2019).

They also endorse and recommend US military intervention in the international system to realize liberal and democratic values and ideals (Blinken and Kagan:2019). Therefore, Biden, on the one hand, states that diplomacy should be the first instrument of American power and that diplomacy will be promoted as the main instrument of American foreign policy (Biden:2020). On the other hand, it does not in any way deny the deployment of US military forces and the use of hard power in other parts of the world. He only argues that force cannot be used unless the "cost" of force is reasonable and adequate (Clemons: Aug. 22.2016).
As chairman of the Senate Foreign Relations Committee, Biden endorsed the US invasion of Iraq in 2009 and voted in favor of it.

He has also recently made it clear that "if Iran chooses to confront the United States, I am ready to defend our vital interests and forces" (Biden: Sept.13.2020). For this reason, Robin Wright described President Biden as a " Mix of principle and pragmatism."(Wright: Nov. 11.2020). Steve Clemons called him the first example of "American personality realism" (Clemons: Aug.22.2016)

US Secretary of State Anthony Blinken has a similar personality, thinking, and performance. Like Biden, he is an internationalist or a liberal realist; In a way that combines adherence to liberal principles and values with the politics of power and political pragmatism. He is realistic, cautious, step-by-step politics, thinking, compromising, and performing.

However, at the same time, it does not ignore the prospects and horizons of the long-term and larger ideals and goals of liberal politics (Fried:2020). In the context of liberal realism, he defines preventive diplomacy and military deterrence as one of the principles of American foreign policy. Accordingly, diplomacy must be complemented and strengthened by deterrence. Moreover, military force is an essential complement to active diplomacy. In his view, responsible foreign policy seeks to prevent or contain crises before they get out of control.

This also requires a combination of active diplomacy and military deterrence (Blinken and Kagan:2019).

The most prominent feature of Blinken, who draws him closer to the realists, is his firm belief in American military intervention in different parts of the world. Biden's national security adviser, Jake Sullivan, also emphasizes the need to integrate pragmatism and idealism into US foreign policy and the need for US leadership in the world.

Based on American exceptionalism, he argues that America's lasting and effective power stems from its strong, credible, and innovative diplomacy, which is exposed to the threat of military force and power (Sullivan:2019).

As a result, he has made it clear that the Biden administration will maintain credible military deterrence as a backbone of diplomacy (USIP: Nov.24.2020).

CIA Director William Burns, one of the masterminds and negotiators of the nuclear talks leading up to the JCPOA, emphasizes the need for military leverage to support diplomacy (Burns: Dec. 8.2019).

\section{Principles of Biden Foreign Policy}

Biden's principles of foreign policy, defined in terms of the elements of liberal internationalist discourse, can be summarized and explained in these cases. Liberal Institutionalism, Multilateralism, Transatlanticism, Human Rights and the Expansion of Democracy, and International Interventionism. 


\subsection{Liberal institutionalism}

Liberal institutionalism, as stated, is one of the elements of liberal internationalist discourse and the principles of Biden's foreign policy.

Liberal institutionalism is a view that argues that international cooperation in international relations can be enhanced through the establishment, development, and support of international institutions based on liberal principles and values (Keohane:2012 pp125). International institutions are stable and relevant rules (formal and informal) that prescribe behavioral roles, limit and constrain activities, and shape expectations (Keohane:1989 pp3). Hence, liberals believe in the practical and constructive role of international institutions, regimes, and organizations in the international system. International institutions play an independent and influential role in establishing and sustaining a liberal international order, the possibility of achieving international cooperation, collective security, and lasting global peace in such a way that international institutions can be used to increase or consolidate the interests of world peace, such as economic interdependence and increase the cost of war, including through the collective punishment of aggression. International institutions play these positive functions through international organizations, especially the United Nations, as their arms and executive mechanisms (Lepgolld and Nincic, 2001:142). According to internationalists or liberal realists, international rules and institutions are the infrastructure of the international system and, therefore, have a central place in the pursuit of America's global interests; International rules and institutions are a powerful tool for American foreign policy that exponentially increase the country's national power in a variety of ways (Ikenberry and Kupchan, 2004:43-44). Accordingly, Jake Sullivan describes the position of institutionalism and the role of international institutions in American foreign policy as follows:

Establishing institutions to share tasks and responsibilities for common issues is part of America's DNA, and on the world stage, it enhances America's institutionalization, power, influence, and efficiency (Sullivan,2019). Anthony Blinken similarly said that the United States could best exercise its power through a set of international rules, norms, principles, and institutions. He argues that the international order of the rule of law has legitimized, maintained, and, in fact, strengthened our power. He considers the nuclear talks with Iran and JCPOA one of the most essential and successful examples of international institutionalism in US foreign policy. "Since we practically renewed our leadership at the United Nations and worked in the Security Council to advance the nuclear negotiations with Iran" (Blinken, 2016).

\subsection{Multilateralism}

The second element of the discourse of liberal internationalism and Biden's principles of foreign policy is Multilateralism. Multilateralism is defined as coordinating national policies in groups of three countries, mainly through special arrangements or institutions (Keohane, 1990:731). Thus, Multilateralism is the opposite of unilateralism, based on which countries formulate and implement their policies without coordination alone. Multilateralism is manifested in the form of various collective economic, political, security, and defense arrangements and institutions, especially within the framework of the United Nations (Walker, 2004; Smith and Laatikainen, 2020). Multilateralism as an action is based on a kind of mentality, perception, and way of thinking.

Multilateralism as an action is based on a kind of mentality, perception, and way of thinking. In such a way, Multilateralism is first presented in thoughts and ideas before it is manifested in action, and before it becomes a military interaction, it is a kind of worldview (Hanafi, 1997:109).

Historically, one of the hallmarks of American foreign policy has been the oscillation between multilateral and unilateral diplomacy. These contradictory dual policies are pursued in two major conflicting strategies of isolationism and internationalism or "Global engagement" of America in world affairs. In the administration of George W. Bush, for example, unilateral diplomacy took precedence over multilateral diplomacy, justifying the fight against international terrorism. However, one-sidedness and isolationism in US foreign policy under the Trump administration culminated in the "America First" strategy (Kupchan, 2020: 3350-350; Jain and Pascal, 2020). Trump's "America First" strategy included isolationism, unilateralism, protectionism, nationalism, and racism (Blinken and Kagan, 2019) as the "America First" policy of the United States meant "Only Americans" and "American alone" (Burns, 2020; Gardner, 2020:453). This strategy does not believe in Multilateralism and commitment to maintaining the US-led liberal international order and works to undermine and destroy it (Kupchan, 2020:300); to the point that the United States withdrew from some international multilateral treaties, institutions, and agreements, including the JCPOA (Jervis, 2018).

The Trump administration's opposition to Multilateralism and the liberal international order is reflected in the remarks of former Secretary of State Mike Pompeo: "Multilateralism is often seen as an end in itself. The more treaties we sign, the safer we seem to be. The more bureaucrats we have, the better things will be done. We wish the international order to serve our citizens, not to control them" (Gardner,2020:450451). Biden and his foreign policy team strongly criticize Trump's policy of isolationism and unilateralism, especially in the face of Iran's nuclear program (Blinken and Kagan,2019; Burns, 2019:385-386; Biden, 2020). They do not even agree to selective engagement and emphasize US comprehensive engagement in world affairs in the context of Multilateralism, as in their view, Multilateralism and engagement is one of the needs and requirements of the American national interest.

On the Necessity and Importance of Multilateralism, Anthony Blinken said: "We know that there is a clear tactical as well as a political and strategic value in not acting alone... by sitting in a chair around a desk, we can steer the conversation and help shape the results" (Blinken, 2016). 
Blinken cited nuclear talks with Iran leading to the JCPOA as one successful example of Multilateralism in US foreign policy. He said that when Iran's nuclear program was developing, there was no opening for US preventive action. The Obama administration has worked with five other countries for several years to negotiate the most demanding nuclear non-proliferation agreement and the most rigorous and accurate unprecedented verification system. He believes that the United States could never have imposed a regime of economic sanctions on Iran without the cooperation and coordination of its partners, forcing it to accept nuclear talks. Also, without multilateral action, the United States would not have been able to monitor Iran's nuclear program so closely that it would ensure that it would remain purely peaceful (Blinken,2016).

William Burns also attributes US success in halting Iran's nuclear program in JCPOA to multilateral diplomacy (Burns, 2019:380-386).

\subsection{Transatlanticism}

Transatlanticism means strategic partnership and closes economic, political security, and defense relations between the two sides of the Atlantic, namely the United States and Europe. In the context of liberal internationalist discourse, as Blinken points out, one of Biden's central tenets of foreign policy, including toward Iran, will be transatlanticism (Blinken and Kagan: 2019). This principle implies two priorities in Biden's foreign policy. First, strengthening cooperation, partnership, and alliance with the European Union in various thematic areas; Second, the reconstruction and restoration of historical relations with NATO through the development and deepening of security-defense partnership and cooperation within its framework (Bloch and Goldgeier: 2020). Hence, Biden's United States will work with its allies and partners to mobilize collective action to address global threats ( Biden: 2020). Biden, as he puts it, will not only work to restore and repair America's historical partnerships but also will try to redesign them to fit the world today; As contrary to Trump's view, Biden and his team see "the nation's allies as a particular national asset." (Sullivan: 2019). In a way, the United States needs the participation and partnership of its European allies to secure its national interests, which in turn requires the strengthening of transatlantic in the framework of close cooperation with the European Union and NATO (Blinken: 2016).

This principle represents a fundamental shift in US foreign policy toward the European Union and NATO in the Biden administration compared to the Trump era. Because of Trump's unilateral foreign policy, US relations with the European Union and NATO were severely weakened (Gardner: 2020:351-376; Wright: 2020), and European officials openly expressed their concern and dissatisfaction with his transatlantic policies. They emphasized that Europe could no longer rely on the United States for security and self-defense and that it needed to stand on its own two feet (Gardner, 2020:363). Therefore, the United States and the European Union, based on the experience of successful cooperation in the JCPOA, will work again to coordinate and unite to revive it; As President Biden mentioned before his election: " The next president must be able to bring countries together; Re-establish our alliances, and insist on Iran to return to the negotiation table and the JCPOA agreement" (Biden: 2020). Elsewhere, he stressed that "we will work with our allies to strengthen and develop the material for the Iran nuclear deal while addressing other issues of concern" (Biden: 2020) because the United States alone cannot do that (USIP: 2020). He reiterated this policy in a speech on February 20, 2021, at the Munich Security Conference.

\subsection{Development of active democracy and human rights}

Biden's fourth principle of foreign policy is the policy of active democracy and human rights; Protecting human rights and democracy will be one of Biden's foreign policy pillars and priorities. Biden had promised on his campaign website that he would revive the United States' commitment to promoting and developing human rights and democracy worldwide if he won (Avni: 2020). Biden's promise to hold a "Summit for Democracy" and having Anthony Blinken on the board of directors of "Human Rights First" raises the possibility of adopting this policy. Jake Sullivan also states that belief and commitment to the power of American values in the world must be revived. He argues that liberal values, such as human rights and the spread of democracy, are at the heart of a country's foreign policy based on ideas and ideals. In his view, the United States cannot lead the world solely based on pure pragmatism and without regard to liberal and democratic ideals ( Sullivan: 2019). Accordingly, some American analysts advise the Biden administration to return to the JCPOA agreement and reduce and lift sanctions imposed by the Trump Administration by conditional observance and improvement of the human rights situation in Iran ( Berman: 2020). Although improving the human rights situation in Iran will not be a precondition for Biden's return to the JCPOA, it will undoubtedly be an essential element of his foreign policy toward Iran. The human rights issue will play a role in Biden's foreign policy towards Iran in two interrelated ways. First, the US government will maintain and even tighten existing human rights sanctions against the Islamic Republic of Iran. Second, it will use the issue of human rights as leverage and effective bargaining to achieve US foreign policy goals toward Iran; Biden can use human rights sanctions to gain ground on Iran's nuclear program, missile program, and regional influence (Avni: 2020).

\subsection{Liberal interventionism}

Biden's fifth principle of foreign policy is military intervention in international affairs and other countries. This interventionism is justified based on American exceptionalism and American responsibility for maintaining world peace and stability. American exceptionalism believes that the United States has characteristics that give it a unique ability and responsibility to help make the world a better place (Sullivan: 2019). Nevertheless, interventionism's fundamental goal is to expand institutions and all kinds of democratic governance, or in other words, the development of liberalism and democracy throughout the world. 
According to the theory of democratic peace, it is argued that the spread and promotion of liberalism and democracy in other countries facilitates and strengthens world peace and security. Beyond that, the global development and consolidation of liberalism and democracy is a strategic necessity for the national interest and security of the United States. Hence, today, this fashion is justified based on the need to ensure and maintain US national security since these interventions violate the norms and basic rules of international relations, such as the principles of noninterference in countries' internal affairs and national sovereignty (Clapton: 2014:3-6). According to the discourse of liberal internationalism, the United States is assumed to exercise restraint in the exercise of military power and the use of force (Ikenberry, 2009:72). However, the performance and positions of Biden and his foreign policy team are not entirely consistent with this assumption.

Contrary to this principle, Blinken, for example, strongly advocates using force by the United States around the world. He criticizes US policy in Syria due to insufficient use of military force (Blinken and Kagan: 2019). He advocated US military intervention in Libya and reaffirmed US support for the Saudi war in Yemen. Senator Biden called on a favorable vote on the US invasion of Iraq in 2003 and for a "though diplomacy." It is a clear example of a radical interventionist who defends the necessity and desirability of US military intervention in the international system. Therefore, in the event of similar crises and conflicts in the future, he will be one of the first to encourage Biden to intervene militarily and resort to force (Larison: 2020). The Iranian nuclear crisis is no exception. In particular, as mentioned, Biden himself has said that he is ready to use force against Iran (Biden, 2020). William Burns also called Trump's order to withdraw US troops from Syria a betrayal of the country's national interests (Burns, 2019).

\subsection{Biden's interests, goals, and foreign policy tools}

Biden's foreign policy interests, goals, and tools are defined, determined, and pursued based on liberal internationalist discourse and principles.

Thus, unlike Trump's nationalist policy, Biden's internationalist foreign policy is based on a broad definition of American national interests; First, American national interests are not defined solely in direct and immediate defense-security and welfare-economic interests. In addition, it includes defense-security and welfare-economic benefits, which are provided indirectly and through intermediaries. Second, the national interests of the United States include the interests of the world order and its ideological interests so that the expansion of American values and norms in the world arena and the maintenance and strengthening of the liberal international order led by the United States is part of the national interests of this country (Blinken, 2016). The expansion and observance of these values and ideals at the international level is also essential to the American defensesecurity and welfare-economic interests;

Because free, more open, and less corrupt countries are less likely to threaten the American way of life (Sullivan, 2019). In Biden's foreign policy, US economic-welfare interests take precedence over its security-defense interests. In a way, the economic-welfare interests direct the security-defense and strategic interests of the United States. According to Biden, national security is defined as economic security, and the middle class also pursues foreign policy. To counter China's power or any other rival and threat, the United States must strengthen its economic and technological power and innovation and unite democratic economies to maintain a liberal global economy (Biden: 2021). To define and determine Biden's most important foreign policy goals, one must first explain the foreign policy goals based on liberal internationalist discourse in general. According to Joseph Nye, the foreign policy goals of liberal internationalism, which he calls progressive realism, are:

1) Securing the United States and its allies;

2) Maintaining and developing a solid national and international economy.

3) Prevention of environmental disasters such as global diseases and pandemics such as coronavirus

4) Strengthen and develop liberal democracy and human rights within the United States and, if necessary, in other countries.

It is argued that this goal is not achieved by forcing American values on others through coercion. Instead, the development and dissemination of democracy and human rights are achieved better and more through soft power, persuasion, perseverance, and patience. Also, Biden's liberal realist foreign policy implies and requires a long-term approach to establishing and developing a liberal international order by the United States as the most powerful country in the world. Like the United States, as the free and liberal world leader, assumes the responsibility of establishing and maintaining an international order as a global good or commodity (Nye, 2006). Accordingly, Biden's most important foreign policy goals are to rebuild and restore US global leadership, which Trump's isolationist foreign policy has damaged-defending and promoting a liberal international order eroded and destroyed under Trump. Defending and promoting democracy and human rights; Preventing regional hegemony in Eurasia means controlling China, Russia, and Iran; Of course, curbing China's growing power, which has challenged US economic hegemony, is a priority. Arms control, especially strategic weapons. Furthermore, rebuilding America's international credibility, which Trump has severely undermined (Biden, 2021).

The goals of US Middle East policy in the Biden administration can also be summarized as follows:

Prevent nuclear proliferation in the region; Controlling tensions and managing regional crises in the Middle East in the national interest of the United States; Maintaining a regional balance in the Middle East in favor of US allies; Ensuring and maintaining Israel's security, And reviving and pursuing the two governments' policy of forming a Palestinian state alongside Israel. In this context, US foreign policy goals toward Iran are also to prevent Iran from acquiring nuclear weapons. Controlling and limiting Iran's missile power and regional power and influence; And changing the behavior of the foreign policy of the Islamic 
Republic of Iran in line with the regional and global interests and goals of the United States (Goldenberg, Catalano Ewers and Thomas, 2020:4). In the meantime, Biden's priority is to contain Iran's nuclear program as a prerequisite for other US goals.

Accordingly, Biden's foreign policy guarantees the priority and preference of using these levers and tools: Soft power; Diplomacy, especially multilateral diplomacy and coercive diplomacy; Economic sanctions; International and regional alliances and alliances; International institutions, regimes, and organizations, especially the United Nations Security Council; Coercive and selective military Force.

Using Force and military as a last resort to counter immediate and gross threats, preserve and uphold liberal international values and order, and consult with other liberal democracies (Ikenberry and Kupchan, 2004:42-43; Kupchan,2020:322; Bell: 2016). Since in the foreign policy of liberal internationalism, power and coercion must be used with caution, restraint, and constraint in the interests of liberal values (Keohane,2012:127). Biden has said that he will not hesitate to use Force or military Force to defend America's vital interests. However, President Biden has declared "diplomacy" to be the primary tool of US foreign policy (Biden, 2021). President Biden has cited the tools and levers of American foreign policy for achieving its national goals and interests as "The foundations of American leadership lie, above all, in a dynamic economy, unparalleled military power, and universal values. We have relied on these core capabilities and embedded them within a broader international order of rules and institutions through the development and modernization of an unparalleled network of US alliances and partnerships" (Biden, 2016). Some analysts believe in Biden's doctrine based on Biden's foreign policy personality, thoughts, and background. For example, according to Steve Clemens, the Biden Doctrine consists of four components and pillars:

1) The Use of Force and military Force as the last foreign policy tool to defend vital interests with the conscious support and consent of the people and with an evident and achievable goal;

2) Forming, consolidating, and strengthening alliances and coalitions;

3) Accurate understanding and estimation of threats, prioritization, and appropriate response to them

4) Pay attention to the personal and individual dimensions and aspects of foreign policy policy-making and decision-making, which means establishing and using personal connections and relationships to achieve foreign policy goals.

\subsection{Biden's policy}

Statements and declarations by Biden and his foreign policy team suggest that Biden's possible US policy toward the Iranian nuclear challenge will be a joint return to the JCPOA, and this is the policy that Biden promised before the election of 2020. In an interview with Thomas Friedman, he also expressed his commitment to this policy (Friedman: 2020). He reiterated his policy on February 19 February 2021, during a speech at the Munich Security Conference.
However, the main issue is the process and how the United States returns to JCPOA. Since Biden's victory in the US presidential election, there have been two options: "unconditional return" and "conditional return."

It seems that Biden will choose the option of an unconditional return to the JCPOA to stop Iran's nuclear program immediately. President believes the best way to limit missile capability and achieve some degree of regional stability is to control and re-monitor Iran's nuclear program (Friedman, 2020). This policy is based on the logic of thematic connection and can be achieved in two ways: First, the start of urgent negotiations to return the United States to the JCPOA agreement, in order to pave the way for negotiations on a missile program and then Iran's regional influence in the later stages. Second, return to the JCPOA and then in parallel and simultaneously to the missile and regional negotiations. Given the strategic value and sensitivity of missile power and regional influence for the Islamic Republic of Iran on the one hand, and the urgency and vital importance of stopping Iran's nuclear program for the United States, on the other hand, will be a mixed and phased Biden policy. In the first phase, nuclear talks will begin with the return of Iran to the pre-US withdrawal from the JCPOA. In the second stage, negotiations are pursued to strengthen and develop the provisions and timetable of the JCPOA agreement. In the third phase, the Biden government will pursue missile and regional talks in parallel (Goldenberg, Catalano Ewer, and Thomas, 2020).

\section{1) Phase One: Return to the negotiation table}

The first step in Biden's step-by-step nuclear policy toward Iran is to rejoin the JCPOA in return for fulfilling Iran's JCPOA obligations in the form of a return-for-return equation or a commitment-to-commitment equation. Biden described the policy as follows: "If Iran returns to strict adherence to the nuclear deal, the United States will rejoin the agreement" (Biden, September 13, 2020). Biden's national security adviser, Jake Sullivan, has also confirmed that the Biden administration intends to bring Iran back to the JCPOA in 2015 and force it to live up to its commitments. In return, the United States is ready to abide by the terms of the agreement (Jamerson, December 7, 2020) and waive Pompeo's twelve terms (Burns and Sullivan cited in USIP, 2020). Blinken also said that if Iran fully adheres, Biden will rejoin the negotiation table (Harb, 2020). Under the policy, Iran imposes restrictions on its nuclear program and activities, while the United States suspends economic sanctions against Iran. Nevertheless, essential ambiguities and questions remain about implementing the return policy in return for a return to the JCPOA.

First, at Iran's request, will the United States first commit to the JCPOA and suspend and lift sanctions? And at the same time, Iran will begin its return to the JCPOA commitments; Or will President Biden return to the JCPOA after Iran fulfills all its obligations? Second, will the U.S. suspends and lift all sanctions when it returns to JCPOA? or will it gradually suspend and cancel them? Third and most importantly, will President Biden return to the same agreement of 2015 without commotion and act on it? Alternatively, after returning to the JCPOA, will it amend 
and revise some of its materials and clauses? (Ross, December 26 December 2020).

Before taking office and in his first press conference as U.S. Secretary of State, Blinken said Iran must first fully comply with its nuclear obligations; Otherwise, all sanctions will remain in place (USIP, Nov.24, 2020)( Blinken:2021). The positions of U.S. officials show that a return to the JCPOA is not Biden's ultimate goal, but a means to an end.

A return to the JCPOA agreement is the beginning of stopping the nuclear program and containing and limiting Iran's missile capability and regional power, not the end. Therefore, given the failure of Trump's campaign of maximum pressure, a return to the JCPOA is necessary but insufficient.

Returning to the JCPOA is the cornerstone for strengthening and expanding its provisions and prolonging its time and the starting point and launching pad for the JCPOA's expansion into the missile and regional areas (USIP, Nov.24, 2020). Of course, this is desirable for the United States, but it does not necessarily mean that it is successful in further plans.

Many variables are influential in this regard, including the rivalry of the great powers or the actions of the Islamic Republic of Iran, which can affect the Americans' decisions.

\section{2) The second phase: strengthening and deepening of the JCPOA}

The US goal in returning to the JCPOA is to pave the way and prepare the ground for negotiations on issues other than the full implementation of the JCPOA by Iran. In a note written on the CNN website in September 2020, President Biden described the suggestion of returning to the JCPOA as follows:

"The United States will return to the JCPOA agreement as a starting point for further negotiations" (Biden, Se.13,2020). Evidence suggests that, after returning to the JCPOA and suspending some sanctions, President Biden will make its continuation conditional on its review and amendment. At this stage, it seeks to negotiate to strengthen, deepen and develop some of the JCPOA's materials, especially the socalled sunset clauses (Ross, Dec.26, 2020; Friedman, Dec.2, 2020). Officials in the new US administration do not hide the pursuit of this goal in the policy of returning to JCPOA. Before the election, President Biden made it clear that: "The United States would rejoin the agreement and commitment and re-commitment to diplomacy to work with our allies to strengthen and expand it" (Biden, March/April 2020, see also Biden, Sept.13, 2020).

He reiterated the US goal after winning the election: " In consultation with our allies and partners, we will enter into further negotiations and agreements to tighten and extend Iran's nuclear restrictions and constraints." (Friedman, Dec.2, 2020). Blinken also describes the purpose and function of the US back to the JCPOA agreement at this stage as strengthening, deepening, and prolonging the JCPOA's time. He said President Biden would make the nuclear deal more substantial and prolong it if Iran returned to full compliance (USIP, Nov.24, 2020). Like President
Biden, he believes that a return to the JCPOA would put the United States in a better position to negotiate a stronger and longer-term nuclear deal through diplomacy with its allies and partners. Sullivan also stressed that the easing and suspension of sanctions by the United States without ensuring that Iran would not immediately negotiate a subsequent agreement that at least extended the agreed timetable are not possible and practical to start verifying issues and intercontinental ballistic missiles (USIP, November 24, 2020).

\section{Phase 3: Expansion of JCPOA}

The strengthening and expansion of JCPOA's provisions also do not convince Biden's America. Assuming that is achieved, the next goal of the United States, as Biden said, is to extend the JCPOA to other destabilizing activities in Iran's view (Biden, March/April 2020). Anthony Blinken reaffirms Biden's position that by returning to the JCPOA, we will be in a much better position to counter and reverse Iran's other destabilizing activities more effectively (USIP, Nov.24, 2020). Jake Sullivan also argued that the US return to the JCPOA and the lifting of sanctions would provide the basis for further "follow-on negotiation" on broader issues (Jamerson, Dec.7, 2020). US officials refer to destabilizing actions or broader issues as Iran's regional influence and missile program.

\subsection{Iran's missile program}

US officials consider the JCPOA to extend Iran's missile program based on the logic of step-by-step arms control agreements, natural and obvious.

They claim that the JCPOA was the first step in Iran's arms control negotiation process, not the last. Just as the SALT Agreement and the START Treaty between the United States and the Soviet Union led to the signing of SALT 2 and START 2, the initial agreement must lead to other agreements. Therefore, negotiations are necessary to reduce and limit Iran's missile capability to complement the JCPOA agreement. For example, Jake Sullivan, who has been involved in all stages of the nuclear talks from Oman to the JCPOA, has emphasized this logic. He claims that Iranian negotiators have been aware of this step-by-step process since the nuclear talks in Oman (USIP, November 24, 2020). As Biden's national security adviser, in an interview with Farid Zakaria, he reiterated that Iran's missile program is one of the negotiating agendas after the US returns to the JCPOA. In an interview with Thomas Friedman, Biden also said that he would enter into negotiations with other members of the P5 +1 group, which in addition to strengthening the JCPOA, would also include Iran's missile program (Friedman, talks with Joe Biden. December 2, 2020).

\subsection{Iran's regional influence}

According to Biden and his foreign policy team, curbing Iran's regional influence is also part of the Iranian arms control process that needs to be negotiated. Hence, regional negotiations are one of the elements of Biden's policy towards Iran. Biden has openly stated that by leveraging active diplomacy and building international consensus on 
US policy toward Iran, he will more effectively counter Iran's destructive behavior and destabilizing activities in the region to reverse it (USIP: December 2, 2020). Regional negotiations can be done in two ways: First, in the form of a comprehensive and extensive nuclear, missile, and regional negotiation model. This model can be implemented in two ways: simultaneous and concurrent negotiation of all three issues together and a single package. Alternatively, in a stepby-step process after progressing in the final phase of nuclear-missile negotiations. Second, within the model of independent but relevant negotiations. This negotiation model can be implemented in two ways: Simultaneous start of nuclear-missile talks on the one hand and regional talks on the other; Or the start of regional negotiations after reaching a preliminary nuclear-missile agreement.

From the participating and negotiating countries' point of view, three models are possible and conceivable:

- Iran and the 5+1;

- Iran, the P5 + 1 and regional countries, especially Saudi Arabia and the UAE;

- Iran and regional countries without the presence but the support of the $5+1$ group.

- The positions of US officials indicate that US policy is based on a model of independent-stage-parallel negotiations with the presence of Iran and regional countries and the support of the P5 +1 .

After progressing in the nuclear-missile talks and the initial agreement, the regional talks will start simultaneously between Iran and the GCC countries, especially Saudi Arabia and the UAE. Thus, regional negotiations are not a precondition or condition for nuclear-missile negotiations and agreements. Jake Sullivan has well explained the US negotiating strategy (USIP, November 24, 2020). Biden's explanation in an interview with Farid Man also implicitly endorsed this strategy (Friedman, talk with Joe Biden, December 2, 2020).

\section{Conclusion}

Biden has stated that one of his foreign policy priorities is to formulate and pursue the new American policy towards Iran. At the heart of his Iranian politics is also the nuclear deal and the JCPOA agreement. However, from the very first days of his election, the question has been what will be the nature and characteristics of the new US administration's policy towards Iran? This article tried to answer this main question. Based on an analysis of Biden's speeches, letters, and positions and his foreign policy team, it was argued that the dominant discourse in US foreign policy toward Iran was liberal internationalism. In the context of this discourse, Biden's foreign policy is based on these five principles:

1. Liberal institutionalism; 2. Multilateralism; 3. Transatlanticism; 4. Human rights and the spread of democracy; 5. International interventionism.

Biden's nuclear policy is also defined, regulated, and pursued in the context of this discourse and based on these principles.
Biden's United States appears to be pursuing a step-by-step policy that addresses all three strategic issues of Iran's nuclear program, missile capability, and regional influence. By returning to the JCPOA, in the first step, it tries to control Iran's nuclear program through a partnership with Europe, cooperation with China and Russia, and using the capacities of international institutions. Then, strengthen and expand the provisions of the JCPOA and limit and restrict Iran's missile program. Moreover, finally, to curb and limit Iran's regional influence. Therefore, the fact is that President Biden's policy of returning to the JCPOA will be very complex and winding.

Assuming an unconditional return to the JCPOA, the likelihood of a dispute between Iran and the United States over how to fulfill its obligations is very high. Therefore, Biden's return to the JCPOA agreement cannot be considered the end of the Iran-US conflict and even the nuclear case. The US return to the JCPOA has an important strategic implication that must be considered before negotiating.

The key issues are reforming the JCPOA and extending it to Iran's missile program and regional influence. Therefore, based on the plan of these cases by the United States and Europe, Iran must decide. Since these issues are in Iran's vital interests, it is impossible or at least challenging to negotiate them. In this case, the possibility of a dispute between Iran and the United States is very likely and will create a situation that will most likely activate the trigger mechanism by the United States.

Therefore, with the announcement of President Biden's return policy to the JCPOA, Iran may be in a dilemma. In such a way that if it does not accept the return of the United States to the JCPOA agreement, President Biden can persuade other JCPOA members to maintain sanctions and even activate the trigger mechanism that President Trump could not use. On the other hand, if the return to the negotiation table by the United States would be accepted, it will be possible for the United States to activate the trigger mechanism, given the high probability of a dispute over how to implement it. Accordingly, several scenarios for the Islamic Republic of Iran in response to the US policy of returning to the JCPOA are conceivable and probable.

- The first scenario is the return of the United States to Resolution 2295 without a return to the JCPOA. In such a way that the United States fulfills its obligations under this resolution like any other country as a member of the United Nations and a permanent member of the Security Council.

- The second scenario is the return of the United States to the JCPOA without the right to use the trigger mechanism.

- The third scenario is the return of the United States to the JCPOA with the possibility of using the modified trigger mechanism. In this case, the right to use the trigger mechanism would be possible by the request of more than one country; By a majority of votes; Or with the consensus of $5+1$ members.

- The fourth scenario is the unconditional return of the United States to the original JCPOA agreement, without 
any changes and gradual lifting of sanctions, in exchange for Iran's gradual return to its commitments.

- The fifth scenario is the unconditional return of the United States to the original JCPOA, without any change or extension, and the lifting of sanctions in exchange for Iran's unconditional return to the JCPOA's total commitments.

Based on the available evidence and facts, it can be concluded that the first scenario is desirable for Iran but very unlikely. The second scenario is the second preferred one in Iran, but there is practically no possibility of its realization. The third scenario is not practically feasible, as the United States will also demand a change in other provisions of the JCPOA. Historical evidence points to the fact that Iran and the United States have difficulty implementing the fourth scenario; as a result, the United States is activating the trigger mechanism. Iran must focus on implementing the fifth scenario. Although it seems unlikely that the United States will be willing to accept this scenario, it can at least pave the way for implementing the fourth scenario; although it is not optimal for Iran, it is the most probable scenario. Therefore, Iran should reduce the costs of this scenario to a minimum. Also, to build regional trust, Iran should start comprehensive regional talks with regional actors. Finally, Iran must, more or less, relinquish its sovereignty over its missile program and regional influence and declare a nuclear policy red line.

\section{Abbreviation}

- SALT: Strategic Arms Limitation Talks

- START Treaty: Strategic Arms Reduction Treaty

- GCC: Gulf Cooperation Council

\section{References}

[1] Bell, Duncan (2016) Liberal internationalism, Encyclopedia Britannica,
(2016) Liberal internationalism, https://www.britannica.com/topic/liberalinternationalism. access date: December 10, 2020.

[2] Berman, Russell A. (2020) How the Biden Administration Can Implement Effective HumanRightsInitiatives, The National Interest.

[3] Biden, Joe (2020) There's a smarter way to be tough on Iran, https://edition.cnn.com/

[4] 2020/09/13/opinions/smarter-way-to-be-tough-oniran-joe-biden/index.html.

[5] Biden, Jr., Joseph R. (2016) Building on Success: Opportunities for the Next Administration,

[6] https://www.foreignaffairs.com/articles/unitedstates/2016-08-07/building-success.

[7] Biden, Jr., Joseph R. (2018) Foreign Affairs Issue Launch with Joe Biden,

[8] https://www.foreignaffairs.com/print/node/1126638.

[9] Biden, Jr., Joseph R. (2020) Why America Must Lead Again: Rescuing U.S. Foreign Policy After Trump,https://www.foreignaffairs.com/articles/united -states/2020-01-23/why-america-must-lead-again.

[10] Biden, Jr., Joseph R. (2021) The Power of America's Example: The Biden Plan for Leading the
DemocraticWorld to Meet the Challenges of the 21st Century, https://joebiden.com/americanleadership./

[11] Blinken, Antony J. (2016), Multilateral Diplomacy in the Modern World: A Conversation with TonyBlinken, https://www.cfr.org/event/multilateraldiplomacy-modern-world-conversation-tony-blinken.

[12] Blinken, Antony J. and Kagan, Robert (2019) America First' is only making the world worse. Here's abetter approach, https://www.washingtonpost.com/opinions/americafirst-is-only-making-the-worldworse-heres-a-betterapproach/2019/01/01/1272367c-079f-11e9-88e3989a3e456820_story.html.

[13] Blinken, Antony (2021) Top US diplomat Blinken sees Long Road to Iran Deal,https://www.arabnews.com/node/1799626/middl e-east.

[14] Bloch, Agneska and Goldgeier, James (2020) Reviving the trans-Atlantic relationship,

[15] https://www.brookings.edu/blog/order-fromchaos/2020/11/17/reviving-the-trans-atlanticrelationship./

[16] Brennan, David (2020), As Biden Seeks New Iran Deal, Zarif Warns He Must Accept 'Transition of Power'to East, https://www.newsweek.com/bideniran-deal-zarif-1548293.

[17] Brennan, David (2020) Iran Says Trump Foreign Policy Among 'Most Unsuccessful' in U.S. History asUranium Stockpile Blows Limit, https://www.newsweek.com/iran-says-trump-foreignpolicy-mostunsuccessful-us-history-uraniumstockpile-blows-limit-1548311.

[18] Brennan, David (2020) What Antony Blinken Has Said about Key Foreign Policy Issues,

[19] https://www.newsweek.com/what-antony-blinkensaid-about-key-foreign-policy-issues-1549404.

[20] Burns, William and Sullivan, Jake (2020) We Led Successful Negotiations with Iran. Trump's ApproachIsn't Working, Carnegie Endowment for International Peace.

[21] Burns, William (2019) The Back Channel: A Memoir of American Diplomacy and the Case for ItsRenewal, New York: Random House.

[22] Burns, William (2019) An End to Magical Thinking in the Middle East, https://www.theatlantic.com/ideas/archive/2019/12/en d-magical-thinking-middle-east/602953./

[23] Burns, William (2020) The United States Needs a New Foreign Policy,https://www.theatlantic.com/ideas/archive/202 0/07/united-states-needs-new-foreign-policy/614110./

[24] Burns, William (2020) America First' Enters Its Most Combustible

Moment, https://www.theatlantic.com/ideas/archive/2020/08/a merica-first-enters-its-most-combustiblemoment/615808./

[25] Caporaso, J. (1992) International Relations Theory and Multilateralism: The Search for Foundations, International Organization, 46(3).

[26] Clapton, William (2014) Risk and Hierarchy in International Society: Liberal Interventionism in thePost-Cold War Era, Basingstoke: Palgrave Macmillan. 
[27] Clapton, William and Hameiri, Shahar (2012) The Domestic Politics of International Hierarchy: RiskManagement and the Reconstitution of International Society, International Politics, 49(1).

[28] Clemons, Steve (2016) The Biden Doctrine: Has the vice president made a lasting contribution in foreignpolicy?

https://www.theatlantic.com/international/archive/201 6/08/biden-doctrine/496841./

[29] Cox, Robert W. (1997) The New Realism: Perspectives on Multilateralism and World Order,

[30] Basingstoke: Palgrave Macmillan.

[31] Drezner, Daniel W. (2006) What is liberal internationalism? Foreign Policy.

[32] Fouskas, Vassilis K. and Gökay, Bülent (2019) The Disintegration of Euro-Atlanticism and New

[33] Authoritarianism, Switzerland AG: Palgrave Macmillan.

[34] Fried, Daniel (2020) How Tony Blinken sees America,

https://www.atlanticcouncil.org/contentseries/fastthin king/how-tony-blinken-sees-america-biden-secretaryof-state./

[35] Friedman, Thomas L. (2020) Biden: 'We're Going to Fight Like Hell by Investing in America First',https://www.nytimes.com/2020/12/02/opinion/b iden-interview-mcconnell-china-iran.html.

[36] Friedman, Thomas L. (2020) Dear Joe, It's Not About Iran's

Nukes Anymore,https://www.nytimes.com/2020/11/29/opini on/iran-biden-nuclear-scientist.html.

[37] Gardner, Anthony Luzzatto (2020) Stars with Stripes: The Essential Partnership between the

[38] European Union and the United States, London: Palgrave Macmillan.

[39] Geranmayeh, Ellie (2020) Course Correction in USIranian Relations: A Road Map for the Biden Administration,https://ecfr.eu/article/coursecorrection-in-us-iranian-relations-a-road-map-for-thebiden-administration/.

[40] Goldenberg, Ilan (2020) Returning to the Deal: The View from Washington.

[41] Goldenberg, Ilan, Catalano Ewer, Elisa and Thomas, Kaleigh (2020) Reengaging Iran: A New Strategy forthe United States, Center for a New American Security.

[42] Hanafi, Hassan (1997) An Islamic Approach to Multilateralism, in Cox, Robert W. (eds.) The New

[43] Realism: Perspectives on Multilateralism and World Order, Basingstoke: Palgrave Macmillan.

[44] Harb, Ali (2020), Who is Tony Blinken, Biden's incoming secretary state?https://www.middleeasteye.net/news/us-tonyblinken-biden-pick-secretary-state.

[45] Herszenhorn, David M. and Momtaz, Rym (2020) 9 things to know about Antony Blinken, the next USsecretary of state, https://www.politico.eu/article/nine-things-to-thinkabout-antony-blinken./

[46] Ikenberry, G. John and Kupchan, Charles (2004) Liberal Realism: The Foundations of a DemocraticForeign Policy, The National Interest.
[47] Ikenberry, G. John (2009) Liberal Internationalism 3.0: America and the Dilemmas of Liberal World Order,Perspectives on Politics, 7(1).

[48] Ikenberry, G. John (2018) The End of Liberal International Order? International Affairs, 94(1).

[49] Jahn, Beate (2013) Liberal Internationalism: Theory, History, Practice, New York: Palgrave Macmillan.

[50] Jain, Ash and Pascal, Alex (2020) Alliances First: Joe Biden's Historic Opportunity to Reshape GlobalOrder, The National Interest.

[51] Jamerson, Joshua (2020) Biden National Security Adviser Sees U.S. Rejoining Iran Nuclear Deal,

[52] https://www.wsj.com/articles/biden-national-securityadviser-sees-u-s-rejoining-iran-nuclear-deal11607399179.

[53] Jervis, Robert, Gavin, Joshua, Rovner, Francis and Labrosse, Diana N., Fujii, George (2018) Chaos in theLiberal Order: The Trump Presidency and International Politics in the Twenty-first Century, NewYork: Columbia University Press.

[54] Keohane, R. O. (1990) Multilateralism: An Agenda for Research. International Journal, 45(4).

[55] Keohane, Robert O. 2012. Twenty Years of Institutional Liberalism, International Relations, 26(2).

[56] Kupchan, Charles A. (2020) Isolationism: A History of America's Efforts to Shield Itself from the

[57] World, New York: Oxford University Press.

[58] Lake, Eli (2020) Trump's Iran Policy Can Be an Opportunity for Biden, https://www.bloomberg.com/opinion/articles/202011-08/trump-s-iran-policy-can-be-an-opportunity-forbiden.

[59] Larison, Daniel (2020) Understanding Iran's Foreign Policy,https://www.theamericanconservative.com/arti cles/understanding-irans-foreign-policy./

[60] Larison, Daniel (2020) Tony Blinken: The Good, the Bad, and Potentially Ugly,https://responsiblestatecraft.org/2020/11/23/tony -blinken-the-good-the-bad-and-potentially-ugly./

[61] Lemon, Jason (2020) Biden Tells France's Macron He Wants to Cooperate on Iran Policy, Iranian PresidentSays New Admin Must 'Make Up for Past Mistakes', https://www.newsweek.com/biden-tellsfrancesmacron-he-wants-cooperate-iran-policyiranian-president-says-new-admin-must-1546487.

[62] Lepgold, Joseph and Nincic, Miroslav (2001) Beyond the Ivory Tower: International Relations Theoryand the Issue of Policy Relevance, New York: Columbia University Press.

[63] Michael R. Pompeo (2018) After the Deal A New Iran Strategy, https://www.state.gov/after-the-dealanew-iran-strategy./

[64] Miller, Aaron David and Sokolsky, Richard (2020) Biden Must Craft a Foreign Policy for a World the U.S.Doesn't Rule, https://www.politico.com/news/magazine/2020/11/19 /joe-biden-foreign-policy-iranchina-438276.

[65] Nye, Jr., Joseph S. (2020) Can Joe Biden's America Be Trusted? Dec 4, 2020. https://www.projectsyndicate.org/commentary/canjoe-biden-restore-trust-in-america-by-joseph-s-nye2020-12. 
[66] Nye, Jr., Joseph S. (2006) Progressive Realism, https://www.belfercenter.org/publication/progressiverealism.

[67] Paris, Roland (1997) Peace building and the Limits of Liberal Internationalism, International Security, 22(2).

[68] Parsi, Trita (2020) The clock starts now: Biden Must Make the Right Signals to Iran on Nuke Deal,

[69] https://quincyinst.org/2020/11/16/the-clock-startsnow-biden-must-make-the-right-signals-to-iranonnuke-deal./

[70] Patrick, Stewart M. (2020) Making America Decent Again: Biden and the Future of U.S. Human RightsPolicy,

https://www.worldpoliticsreview.com/articles/29219/ making-america-decent-again-biden-andthe-future-ofu-s-human-rights-policy.

[71] Pauly, Robert J. (2016) US Foreign Policy and the Persian Gulf: Safeguarding American Interests

[72] through Selective Multilateralism, London and New York: Routledge.

[73] Ross, Dennis (2020) How Biden's Iran Policy Can Have a Chance to Succeed,

[74] https://www.bnnbloomberg.ca/how-biden-s-iranpolicy-can-have-a-chance-to-succeed-.1541134.

[75] Rubin, Michael (2020) Iran: Why Now Is Not the Time to Abandon Maximum Pressure,

[76] https://nationalinterest.org/feature/iran-why-now-nottime-abandon-maximum-pressure-173955.

[77] Slavin, Barbara (2020) U.S. Hostility with Iran Only Serves Hardliners on Both Sides,

[78] https://foreignpolicy.com/2020/11/19/biden-iranunited-states-share-interests-hardliners./

[79] Smith, Karen E. and Laatikainen, Katie Verlin (2020) Group Politics in UN Multilateralism, Leiden;

[80] Boston: Brill.

[81] Sullivan, Jake (2019) What Donald Trump and Dick Cheney Got Wrong About America,

[82] https://www.theatlantic.com/magazine/archive/2019/0 1/yes-america-can-still-lead-the-world/576427./

[83] Sullivan, Jake (2019) From Theory to Practice: An Interview with Jake Sullivan, World Outlook at the JohnSloan Dickey Center.

[84] Tharoor, Ishaan (2020) Trump's Iran agenda is about to end in failure,https://www.washingtonpost.com/world/2020/ 11/17/trump-iran-pressure-biden-nuclear./

[85] Tom, O'Connor (2020) Biden and Iran Both Want Nuclear Deal, Here's What Stands in Their Way,

[86] https://www.newsweek.com/bide-iran-want-nucleardeal-standing-way-1546356.

[87] United States Institute of Peace (USIP) (2020), Biden Foreign Policy Team on Iran,

[88] https://www.usip.org/events/joe-bidens-toughchallenges-iran.

[89] United States Institute of Peace (USIP), Joe Biden on Iran, https://iranprimer.usip.org/blog/2020/nov/09/joebiden-iran.

[90] Vakil, Sanam (2020) A Regional Security Process for the Middle East, in: Vinjamuri, Leslie (Ed), USForeign Policy Priorities: What Difference Can an Election Make?, Chatham House.
[91] Walker, Ronald A. (2004) Multilateral Conferences Purposeful International Negotiation,

[92] Basingstoke: Palgrave Macmillan.

[93] Walt, Stephen (2020) Biden Sees the A-Team. I See the https://foreignpolicy.com/2020/12/11/bidensees-thea-team-i-see-the-blob.

[94] World Politics Review (2020) U.S. Foreign Policy Under Biden Presidency,

[95] https://worldpoliticsreview.s3.amazonaws.com/WPRBiden-Presidency-US-Foreign-Policy-103020.pdf.

[96] Wright, Robin (2020) The Seven Pillars of Biden's Foreign Policy,

[97] https://www.newyorker.com/news/ourcolumnists/the-seven-pillars-of-bidens-foreign-policy.

[98] Wright, Robert (2006) An American Foreign Policy That Both Realists and Idealists Should Fall in Love With,

https://www.nytimes.com/2006/07/16/opinion/16wrig ht.html.

[99] Wright, Robert (2016) American Foreign Policy Has an Empathy Problem,

[100] https://www.thenation.com/article/archive/americanforeign-policy-has-an-empathy-problem.

[101] Wright, Robert and Echols, Connor (2020) Progressive Realism; Grading Biden's Foreign Policy Team:Tony Blinken, https://nonzero.org/post/bidenforpol-team-1-blinken. 